\title{
Improving the quality of life through participation in physical activity- the tennis camp pilot study
}

\author{
Radu-Tiberiu ȘERBAN ${ }^{1}$, Alin Marius BACIU ${ }^{1}$
}

\begin{abstract}
Aim. Scientific data show an increase in infantile overweight and obesity cases, which results in illness and social problems, thus a lower quality of life. The main causes for this situation are the lack of physical activity, the nutritional behavior and emotional stress. Our attention focused on observing the group's social behavior at the end of the implementation of a program which integrated physical activity, a healthy nutritional behavior and social activities.

Methods. The case study started by abstracting information from scientific publications for a better understanding of the phenomena. The research used the survey method for analyzing the groups' $(n=14)$ social dynamics throughout the implementation of a physical activity program for children aged 8 to 12 .

Results. By comparing the initial and final results of the survey, an improvement of the social relations inside the subjects' group can be observed.

Conclusion. The main knowledge gained from this experiment is the confirmation that through the implementation of strategies that include physical activities, a strict nutritional behavior and social activities, we can improve a group's cohesion and thus contribute to the increase of the quality of life for children aged 8 to 12 years old, although the evaluation of other aspects like the evolution of physical and mental fitness throughout such a program is needed.
\end{abstract}

Key words: physical activity, children, cohesion.

\section{Rezumat}

Scopul. Datele științifice arată o creștere în numărul cazurilor de supraponderalitate și obezitate infantilă, care cauzează ulterior boli și probleme sociale, și astfel o calitate a vieții mai scăzută. Principalele cauze ale acestei situații sunt lipsa activității fizice, comportamentul nutrițional și stresul emoțional. Atenția noastră s-a îndreptat spre observarea comportamentului social al grupului studiat la finalul implementării unui program care a integrat activitate fizică, un comportament nutrițional sănătos și activități sociale.

Metode. Studiul de caz a început prin culegerea de informații științifice pentru o mai bună înțelegere a fenomenului. Cercetarea a folosit metoda chestionarului pentru a analiza dinamica socială a grupului $(n=14)$ pe parcursul implementării unui program de activitate fizică pentru copii cu vârste cuprinse între 8 și 12 ani.

Rezultate. Comparând rezultatele inițiale și cele finale ale chestionarului, a putut fi observată o îmbunătățire a relațiilor sociale din grupul studiat.

Concluzie. Informația principală dobândită în urma acestui experiment este confirmarea că prin implementarea de strategii care includ activități fizice, un comportament nutrițional strict și activități de socializare se poate îmbunătăți coeziunea unui grup și astfel se aduce o contribuție și la creșterea calității vieții copiilor cu vârste cuprinse între 8 și 12 ani, deși este necesară și evaluarea altor aspecte precum evoluția fitnessului fizic și mental pe parcursul unui asemenea program.

Cuvinte cheie: activitate fizică, copii, coeziune

\footnotetext{
${ }^{I}$ PhD Students, Babes-Bolyai University of Cluj-Napoca, Romania, Faculty of Physical Education and Sport, e-mail: serban.rt@gmail.com
} 


\section{Introduction}

Information published in studies show that worldwide, overweight is a concern for the health of children. At an european level studies [8] say that the presence of child obesity is increasing, mostly in countries in eastern and south-eastern Europe. This increase is also shown by studies in the United States of America, Brazil, Russia or China [15].

Excess weight is the most common factor of circulatory illness [7] and also one of the factors that improve the less over time in the case of the ones diagnosed with heart ilness. In the recent past, several studies enfacized that obesity causes cardiovasculary iless through various means.

Obesity in children and adolescents represents a risk factor for circulatory ilness [9], high blood pressure [13], tipe 2 diabetes, sleep apnee syndrome [10], depression [6] and even some forms of cancer.

Recent years studies on the child overweight and obesity phenomena, lead to designing national policies for its management. A study [11] compared six of these policies, and found that the recommendations offered by these different statal authorities seem to be simmilar, a common trait being that a combined intervention: nutritional diet, physical activity and counciling; is considered to be the most efficient. The same study says that however there are some differences in the classification of the diagnose regarding child obesity.

In Romania, studies on this theme enfacize an increase of overweight cases in primary and secondary school [3]. A study that measured a group of 7904 children in Cluj-Napoca in the year of 2008 , has shown a prevailance of $12,8 \%$ overweight cases and $8,3 \%$ obesity cases.

The most worrying prevailances was recorded in the case of children aged 6 to 10 years old and the lowest in the case of teenagers $(7,6 \%$ were overweight and 3,8\% were obese) [14].

As it is well known, the relationship between sport and physical health is a major concern of medicine, physiology, sports science and psichology. This relationship also enters the sector of sociology research, as public health, and having the surveys, questionnaires and interviews as main research methods. Through this kind of research, the authors enfacized significantly positive associations between practicing sports and a better physical and psychical health. Thus, in the early 90's extended surveys were made on representative national populations counting between 3500 and 6500 subjects, some designed and applied by the Public Census and Investigation Office.

Some positive associations were made between the regular practice of sports and the physical and mental health status. This association though does not prove that sports on a mass scale automaticly determines the optimization of health because the causal relation might be the exact opposite. Although, other studies show that in spite of the existence of this two way relation, practicing physical activity improves and maintains health.

Starting with the work of Dumazeider $[4,5]$.

some sociologists underline that the physical function of sport (the benefits of sports on health) leads to an indirect function, the social well being. In short, the reasoning is as follows: since physical activity and sport produce a high physical and psychological tone, the feeling of relaxation and good mood, they are a kind of compensation for the anxiety and alienation generated by the work itself.

Socialization is the process through which the individual, being in interaction with his fellows, accumulates skills, knowledge, values, norms, attitudes and ways of behaving [12].

Socialisation in sport influences different individual behavioral spheres and the social life in general. It is wel known that practicing sports and physical exercise have a positive role in physical and mental health, especially in a more and more sedentary society

If we try correlating the peoples' quality of life and the ways of spending the leisure time it is easily noticeable that the high percentages of people practicing sports is an indicator of the development of a society.

Aknowledging the fact that the way of living (including the practice of sports) has a major impact on health and life expectancy.

The quality of life is an evaluation concept and is being the result of the reporting of living conditions and activities that make up human life, to human needs, values, aspirations.

As stated by Zamfir [16] the quality of life refers to both the overall assessment of life (how satisfactory is the life that different people, social groups, 
collectives live), as well as the assessment of different conditions or spheres of life.

When talking about the quality of life, the following components are considered:

a) The quality of the surrounding environmend;

b) The worklife quality;

c) The interpersonal relationship quality;

d) The family life quality.

From this perspective, thic concept can overlap with the happiness concept. Though, while happiness is a subjective state resulted from living one's own life, the quality of life refers to the objective data regarding the human life, classified in indicators of the quality of life.

Starting with the evolution of the social measurements techniques, researchers tryed to measure the quality of life as a whole, through aggregating a large variety of objective measurements. This tendency started in the 1970's and was called "the research on the quality of life" [2].

The above mentioned indicators are goupt in several dimensions, of which we enfacize the following:

1) Spare time, rest, tourism, holidays and sport:

- The time budget structure;

- Spare time proportion of the total time budget;

- The spare time structure;

- Rest, tourism, holidays, sport;

- $\quad$ Spare time financial expendure.

2) Culture, human relations, attitudes and opinions:

- The spread of culture and art among populations;

- The access of populations to culture and art;

- The state's expendure for the functioning of cultural and art institutions;

- The goals of the populations.

3) Health protection and social security:

- Te population's health status;

- The frequency and causes of morbidity and mortality;

- The population's medical services coverage and the accessibility of the population to health assistance;

- The endowment and structure of the health network;

- $\quad$ Expendures for health maintenance;
- Social security (pensions, social protection, child allowances).

In the USA for example, there is an annual social accounting report, under the name of Social Indicators. As Carley [2] states, the most frequent sections of these reports are: population; family; housing; security and social well-being; health and nutrition; public safety; education and training; work; income, health and expenditure; culture, leisure time and use of this time (loisir); mobility and social participation.

With some differences, the entire world's states account for such components of social status at some point in search of adequate social and budgetary policies to improve the quality of life.

The practice of sport seems to be a marginal component of the quality of life, although many studies have shown that there are strong positive correlations between living standards, quality of life and the level of development of national sports institutions (and the practice of large-scale physical activities among the population). Therefore authors of the quality of life.

\section{Purpose and objectives}

The purpose of our research is to study the social effects (group cohesion) of the implementation of a program (The Tennis Camp Program) for children aged 8 to 12 years old. Our main objectives were:

- Planning a detailed schedule which aggregated physical activity, a strict nutritional behaviour and social activities;

- Testing the practicability of the program;

- Verifying the instruments (the group social matrix test);

- Observing the eventual evolution of group cohesion and state of acceptance among the participants' group.

\section{Materials and methods}

The pilot study, included a group of children $(n=14)$ that are playing tennis in Napoca Tennis Club in Cluj-Napoca. The sampling has been made through the volunteering of the participants. The study was organized by the coaches of the above mentioned sports club. The design of the research started with a brain storming session involving the tennis club's coaches, the parents of the children, and students 
from the Faculty of Physical Education and Sports in Babes-Bolyai University of Cluj-Napoca.

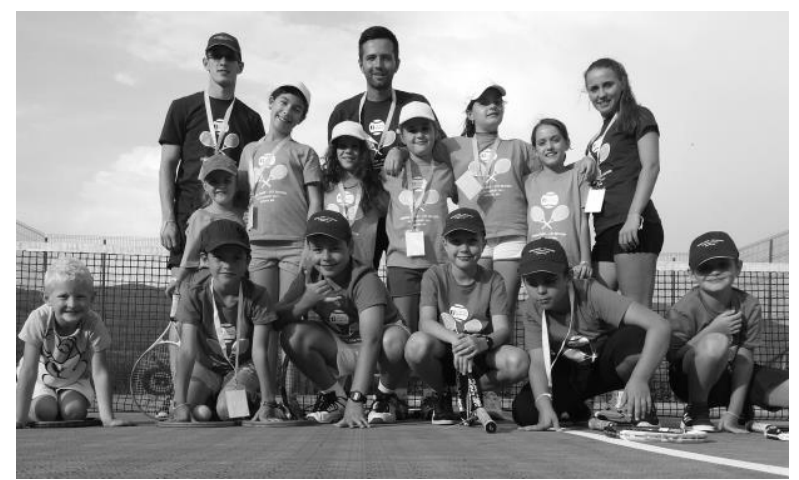

Figure 1 - Group photo of the subjects and coaches

The researchers took the specific objectives of tennis into account, aknowledging the age particularities of the future subjects, and planned a three day tennis training schedule. Among the physical, technical, tactical, theoretic and psychological components of the training, the recommendations for a healthy nutritional behavior were used for defining the timetable. Also, organized socializing activities were included in the schedule.

At the end, the three day schedule included 7 physical activity sessions (morning revival activities, tennis training, physical fitness exercises and dynamic games) and 5 theoretical courses lectured by the participying coaches. (The history of tennis, The sports facilities, Performance sport vs. Physical education, Tennis refereeing, Tennis racket stringing).

Regarding the nutritional behaviour, the children were only allowed to eat the food offered by the organizers at the precise times of the day (8AM, 1PM, 7PM) and small snacks (fruit and cereal bars) between theese hours. The nutritional plan was built to fulfill the speciality's recommendations. Water consumption was encouraged throughout the day.

Social activities filled the gaps between physical activities and theoretical courses. They included bonding games, watching sports motivational videos, imitating sportsmen behaviors (e.g.: giving interviews).

The test we decided to use for studying the group's social dynamic is the social matrix test. This test requires that the subjects fill in a line of a matrix with integer numbers between -1 and 1 . Each column represents one of the members of the group. In each matrix cell, representing the intersection between the subject's line and the other subjects'columns, the respondents must fill in with „- 1 " if he has rejection feelings regarding the other subject, „0" if he has neutral feelings regarding the other person or "1"if the subject has positive feelings towards the other participant.

As the Tennis Camp program took place, in Sovata, Romania, away from Cluj-Napoca and knowing that most children did not know the each other at the begining of the activity, they took the first social matrix test before leaving Cluj-Napoca. At the end of the three day intervention they took the retest in order to compare the results.

\section{Results}

At the end of the program we were able to compare the answers to the initial and final matrixes. As seen below, each number on the first row and the first column represents the subjects. The intersections between a subjects row and his column is marked with „X” as he did not have to offer himself a score. The other scores represent each subject's feelings towards the colleagues un each column.

Table 1 Initial results of the social matrix test

\begin{tabular}{|l|l|l|l|l|l|l|l|l|l|l|l|l|l|l|}
\hline $\mathbf{T i}$ & $\mathbf{1}$ & $\mathbf{2}$ & $\mathbf{3}$ & $\mathbf{4}$ & $\mathbf{5}$ & $\mathbf{6}$ & $\mathbf{7}$ & $\mathbf{8}$ & $\mathbf{9}$ & $\mathbf{1 0}$ & $\mathbf{1 1}$ & $\mathbf{1 2}$ & $\mathbf{1 3}$ & $\mathbf{1 4}$ \\
\hline $\mathbf{1}$ & $\mathrm{X}$ & 1 & 0 & 1 & 1 & 1 & 1 & 0 & 0 & 1 & 0 & 0 & 0 & 0 \\
\hline $\mathbf{2}$ & 1 & $\mathrm{X}$ & 1 & 1 & 1 & 1 & 0 & 1 & 1 & 1 & 1 & 0 & 0 & 0 \\
\hline $\mathbf{3}$ & 0 & 1 & $\mathrm{X}$ & 1 & 0 & 1 & 1 & -1 & 1 & 1 & 1 & 1 & 1 & 1 \\
\hline $\mathbf{4}$ & 1 & 1 & 1 & $\mathrm{X}$ & 1 & 1 & 1 & 1 & 1 & 1 & 1 & 0 & 0 & 0 \\
\hline $\mathbf{5}$ & 0 & 1 & 0 & 1 & $\mathrm{X}$ & 1 & 0 & -1 & -1 & 1 & -1 & 0 & 0 & 0 \\
\hline $\mathbf{6}$ & 1 & 1 & 1 & 1 & 1 & $\mathrm{X}$ & 1 & 1 & 1 & 1 & 1 & 1 & 1 & 0 \\
\hline $\mathbf{7}$ & 1 & 1 & 1 & 1 & 1 & 1 & $\mathrm{X}$ & 0 & 0 & 1 & 0 & 1 & 0 & 0 \\
\hline $\mathbf{8}$ & 0 & 0 & 1 & 1 & 0 & 1 & 0 & $\mathrm{X}$ & 1 & 1 & 1 & -1 & 0 & 0 \\
\hline $\mathbf{9}$ & 1 & 1 & 1 & 1 & 1 & 1 & -1 & 1 & $\mathrm{X}$ & 1 & 1 & 1 & 0 & -1 \\
\hline $\mathbf{1 0}$ & 1 & 1 & 1 & 1 & 1 & 1 & 1 & 1 & 1 & $\mathrm{X}$ & 1 & 1 & 1 & 1 \\
\hline $\mathbf{1 1}$ & 1 & -1 & 0 & 1 & -1 & 1 & -1 & 1 & 1 & 1 & $\mathrm{X}$ & 1 & 0 & 0 \\
\hline $\mathbf{1 2}$ & 1 & 0 & 1 & 0 & -1 & 1 & 0 & -1 & 0 & 1 & 1 & $\mathrm{X}$ & 0 & 1 \\
\hline $\mathbf{1 3}$ & 0 & 0 & 0 & 0 & 0 & 0 & 0 & 0 & 0 & 1 & 0 & 0 & $\mathrm{X}$ & 0 \\
\hline $\mathbf{1 4}$ & 0 & 0 & 0 & 0 & 0 & 0 & 0 & 0 & 0 & 1 & 0 & 0 & 0 & $\mathrm{X}$ \\
\hline
\end{tabular}


Table 2 - Final results of the social matrix test

\begin{tabular}{|l|l|l|l|l|l|l|l|l|l|l|l|l|l|l|}
\hline Tf & $\mathbf{1}$ & $\mathbf{2}$ & $\mathbf{3}$ & $\mathbf{4}$ & $\mathbf{5}$ & $\mathbf{6}$ & $\mathbf{7}$ & $\mathbf{8}$ & $\mathbf{9}$ & $\mathbf{1 0}$ & $\mathbf{1 1}$ & $\mathbf{1 2}$ & $\mathbf{1 3}$ & $\mathbf{1 4}$ \\
\hline $\mathbf{1}$ & $\mathrm{X}$ & 1 & 1 & 1 & 1 & 1 & 1 & -1 & -1 & 1 & -1 & 1 & 1 & 0 \\
\hline $\mathbf{2}$ & 1 & $\mathrm{X}$ & 1 & 1 & 1 & 1 & 1 & -1 & -1 & 1 & -1 & -1 & 1 & 1 \\
\hline $\mathbf{3}$ & 1 & 1 & $\mathrm{X}$ & 1 & 1 & 1 & 1 & 0 & 1 & 1 & 1 & 1 & 1 & 1 \\
\hline $\mathbf{4}$ & 1 & 1 & 1 & $\mathrm{X}$ & 1 & 1 & -1 & 1 & 1 & 1 & -1 & 1 & 1 & 1 \\
\hline $\mathbf{5}$ & 1 & 1 & 1 & 1 & $\mathrm{X}$ & 1 & 1 & -1 & -1 & 1 & -1 & 0 & 0 & 0 \\
\hline $\mathbf{6}$ & 1 & 1 & 1 & 1 & 1 & $\mathrm{X}$ & 1 & 1 & 1 & 1 & 1 & 1 & 1 & 1 \\
\hline $\mathbf{7}$ & 1 & 1 & 1 & 1 & 1 & 1 & $\mathrm{X}$ & -1 & -1 & 1 & -1 & 1 & 1 & 1 \\
\hline $\mathbf{8}$ & 0 & 0 & 1 & 1 & -1 & 1 & -1 & $\mathrm{X}$ & 1 & 1 & 1 & -1 & 1 & 0 \\
\hline $\mathbf{9}$ & 1 & -1 & 1 & 1 & 1 & 1 & 0 & 1 & $\mathrm{X}$ & 1 & 1 & 1 & 1 & -1 \\
\hline $\mathbf{1 0}$ & 1 & 1 & 1 & 1 & 1 & 1 & 1 & 0 & 1 & $\mathrm{X}$ & 1 & 1 & 1 & 1 \\
\hline $\mathbf{1 1}$ & 1 & -1 & 1 & 1 & -1 & 1 & 1 & 1 & 1 & 1 & $\mathrm{X}$ & 1 & 1 & -1 \\
\hline $\mathbf{1 2}$ & 1 & -1 & 1 & -1 & 0 & 1 & 0 & -1 & 0 & 1 & 1 & $\mathrm{X}$ & 0 & 0 \\
\hline $\mathbf{1 3}$ & 0 & 0 & 1 & 1 & 0 & 1 & 0 & 1 & 1 & 1 & 1 & 1 & $\mathrm{X}$ & 0 \\
\hline $\mathbf{1 4}$ & 0 & 0 & 1 & 1 & 1 & 1 & 0 & 0 & 0 & 1 & 0 & 0 & 1 & $\mathrm{X}$ \\
\hline
\end{tabular}

First of all we noticed an increase of the total sum of the response indexes, and a lower number of „0"cases. Considering a maximum group cohesion as having all the answers equal to "1", the social matrix sum should be, in this case, 182 (100\% cohesion). The initial measurement offered a social matrix score of 91 ( $50 \%$ cohesion) and the second a score of 103 (56.6\% cohesion), thus an increase.

Although, this is not considered a statistically significant difference (as shown in Table 3) it can still be considered as an improvement of the group cohesion.

Table 3 - Paired samples test for group cohesion

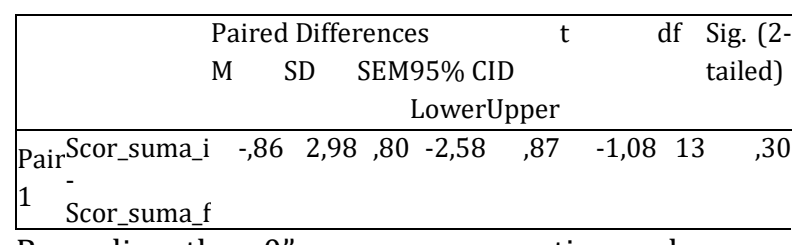

Regarding the „0" answers we notice a decrease form a frequency of 66 (36.26\% of the maximum possible) to 25 (13.74\%), which as shown in Table 4 represents a statistically significant difference.

Table 4 - Paired samples test for intra-group relationships

\begin{tabular}{|c|c|c|c|c|c|c|c|c|}
\hline & \multicolumn{4}{|c|}{ Paired Differences } & \multirow[t]{2}{*}{$\mathrm{t}$} & $\mathrm{df}$ & \multirow{2}{*}{$\begin{array}{l}\text { Sig. (2- } \\
\text { tailed) }\end{array}$} \\
\hline & & $\mathrm{M}$ & SD & $\begin{array}{r}\text { SEM95\% } \\
\text { Lowe }\end{array}$ & $\begin{array}{l}\text { CID } \\
\text { rUppe }\end{array}$ & & & \\
\hline $\begin{array}{l}\text { Pair } \\
1\end{array}$ & $\begin{array}{l}\text { Scor0_i - } \\
\text { Scor0_f }\end{array}$ & 2,93 & 2,81 & 75 1,30 & 4,55 & 3,89 & 13 & ,002 \\
\hline
\end{tabular}

\section{Discussions}

This pilot test has reconfirmed the fact that through physical activity we can influence the group's social dynamics regarding cohesion, and thus influence the objective indexes of the quality of life shown by sociology specialists. Of course that in the future, a simmilar study should develop the method of assesing the groups social dynamics and also include a monitoring system for the physical and mental fitness throughout the program.

A longer period of time for the implementation of a strategy like this is needed in order to sutain more consistent behavioral improvements and of course follow-up actions could empower the changes made.

\section{Conclusions}

We can notice that even through a simple intervention aggregating physical activity, strict nutritional planning and social activities we can influence group behaviour and interpersonal relationships. This stands as a confirmation of the benefits of physical activity on the well being of children.

In a broader future research we will use the information gained from this pilot study to improve the way of assesing the group's social dynamics.

\section{References}

1. Baciu A. M. (2006). Sportul și calitatea vieții: Caz special tenisul de câmp. Cluj-Napoca: Editura Napoca Star.

2. Carley M. (1981). Social measurement and social indicators. London: George Allen and Unwin.

3. Coșoveanu C. S. (2011). Universitatea de Medicină și Farmacie din Craiova. Retrieved 10 4, 2015, from http://www.umfcv.ro/files/o/b/Obezitatea\%20primara\%20la\% 20copil, $\% 20$ aspecte $\% 20$ etiopatogenice, $\% 20$ clinice $\% 20 \mathrm{si} \% 20 \mathrm{pr}$ ofilactice.pdf

4. Dumazeider J. (1950). Regards neufs sur le sport, moyen de culture. Paris: Le Seuil.

5. Dumazeider, J. (1962). Vers une civilisation des loisirs. Paris: Le Seuil.

6. Hedley A., Ogden, C., Johnson, C., \& Carroll, C. L. (2004). Prevalence of overweight and obesity among US children, adolescents, and adults, 1999-2002. JAMA, 2847-2850.

7. Lopez-Jimenez F., \& Cortes-Bergoderi M. (2011). Obesity and the Heart. Revista Espanola de Cardiologia, 140-149.

8. MBE Livingstone. (2001). Childhood obesity in Europe: a growing concern. Public Health Nutrition: 4(1A), 109-116.

9. Ogden C., Flegal K., Carroll M., Johnson C. (2002). Prevalence and trends in overweight among US children and adolescents, 1999-2000. The Journal of the Americam Medical Association, 1728-1732. 
10. Papandreou I., Lim A., Laderoute K., Denko N. (2008). Hypoxia signals autophagy in tumor cells via AMPK activity, independent of HIF-1. Cell Death Differ, 1572-1581.

11. Richardson L., Paulis W. D., van Middelkoop M., Koes B. W. (2013). An overview of national clinical guidelines for the management of childhood obesity in primary care. Preventive Medicine 57, 448-455.

12. Rotariu T., Iluț P. (1996). Sociologie. Cluj-Napoca: Editura Mesagerul.

13. Summerbell C., Waters E., Edmunds L., Kelly S., Brown, T., Campbell K. (2005). Interventions for preventing obesity in children. Cochrane Database of Systematic Reviews, 1-70.

14. Văleanu C., Tătar S., Nanulescu M. (2009). Prevalence of obesity andoverweight among school children in Cluj Napoca. Acta Endocrinologica 5(2), 213-219.

15. Wang Y., Monteiro C., Popkin B. (2002). Trends of obesity and underweight in older children and adolescents in the United. American Journal of Clinical Nutrition, 971-977.

16. Zamfir C. (1993). Dictionar de sociologie. București: Editura Babel. 